\title{
Yoga, Chronic Pain and Psychological Well-Being
}

\author{
Pamela Potelli* \\ Department of Psychology, University of Malta, Malta
}

Submission: August 16, 2017; Published: August 22, 2017

*Corresponding author: Pamela Potelli, Department of Psychology, Faculty of Social Wellbeing, University of Malta, Malta, Email: pport03@um.edu.mt

\section{Introduction}

Pain is an inevitable and unavoidable universal human experience. The International Association for the Study of Pain (IASP) defines pain as 'an unpleasant sensory and emotional experience associated with actual or potential tissue damage or described in terms of such damage' [1]. Unrelieved pain becomes chronic in nature when it persists for more than 3 months. [1] Chronic pain is often characterized by varying pain intensity, with onset and duration being fairly unpredictable. Chronic pain affects between 12 to $25 \%$ of the adult population in the US and 19\% of Europeans [2,3]. Despite its crucial role for survival, pain becomes problematic when it is enduring, persistent and dominating and when it impairs the quality of life of the sufferer. Living with pain on a day-to-day basis can be exhausting, especially when no pain relief is available [4]. Psychological factors play a crucial role in the experience of pain [4]. The individual's beliefs, thoughts, coping mechanisms, expectations, emotions, self-efficacy, locus of control and perceived limitations due to the pain are important aspects influencing pain perception and coping $[5,6]$.

Pharmacological and physical interventions are often the first line of treatment for managing pain. Since symptoms of depression, mood disturbance, insomnia, and anxiety often co-exist with chronic pain conditions, psychotropic drugs are popularly prescribed [7]. While medical interventions play a crucial role in alleviating pain, they have their limitations including unpleasant side effects, tolerance and physical dependence [8]. Apart from that, some chronic pain problems are difficult to diagnose and medicine may only provide temporary relief [9]. Despite advances in medical pharmacology, the treatment of unrelieved pain remains a challenge. Up to this day, cure for certain pain conditions such as fibromyalgia have not been identified [10]. Chronic pain management is also expensive, mostly due to the need for long-term treatment. The accepted gold standard treatment for the management of chronic pain in most health centers relies on a multi-disciplinary approach consisting of feedback from diverse health care professionals working closely with the patient to ensure a holistic treatment plan [11]. Individuals differ in how they respond to life stressors and pain coping is subjective and multi-factorial [12]. According to the Fear Avoidance Model [13], the individual's perception and appraisal of the pain experience will result in one of two outcomes, avoidance or confrontation. Confrontation entails taking adaptive action and early mobilization from a perceived temporary setback. In a pain context, this may entail graded exercises and stretching to avoid further pain complications, for instance [14]. Avoidance comprises pain-related fears, sedentary lifestyles, pain hyper-vigilance and catastrophizing. Unfortunately, individuals resorting to avoidance strategies are more likely to suffer from increased physical disability and pain exacerbation [14]. Yoga is an ancient contemplative practice dating back over 3,500 years. It aims to reduce suffering and promote physical and mental health via the achievement of a mind-body balance [15]. Practicing yoga was found to reduce psychiatric symptoms and foster psychological well-being [16]. Birkam yoga and intense physical exercise were found to have a beneficial effect on core self-evaluation [17]. The latter is a holistic term comprising a positive self-concept, self-esteem, self-efficacy, locus of control and emotional stability. Yoga practice can also facilitate the process of self-development and improve self-regulation [18]. When applied to a health context, self-regulation entails the conscious effort, motivation and will power to guide one's thoughts, actions and feelings to reach one's goals, reduce sickness behavior and improve mobility [19].

Diverse studies exploring whether yoga can help individuals with chronic pain reveal promising findings. Yoga has been found to be effective in chronic pain conditions and in improving physical functioning $[18,20]$. It has also been found to support changes in chronic illness schemas by challenging beliefs about the limits of one's physical body, reducing learned helplessness and mitigating dysfunctional coping behavior $[18,21]$ Individuals practicing yoga weekly report less pain interference, less pain episodes and frequency [22]. A trial revealed that practicing yoga was associated with improved psychological well-being including improved quality of life, decreased symptoms of 
depression, fatigue, functional disability, anger and hostility and an enhanced mood $[23,24]$.

One of the most feasible yoga styles for chronic pain patients is lyengar yoga [23]. Lyengar yoga comprises posture sequences and supportive props such as belts, chairs, blankets and blocks that allow for a safer yoga practice, thereby facilitating ease of flexibility, stability, mobility and alignment. Thus, yoga can be particularly beneficial for chronic patients who have uncomplicated pain conditions and whose pain is not attributed to specific underlying diseases or serious comorbidities [23].

\section{Conclusion}

Given the promising findings, a number of measures can be taken to increase the uptake of yoga practices and improve the overall quality of life and psychological well-being of chronic pain sufferers. An increased collaboration between health-care providers and yoga instructors is needed to ensure that clients are directed to safe practices and trusted entities. Health-care professionals need to have a thorough understanding of what these practices entail in order to ensure that clients under their care are directed to services targeting their specific health needs. Chronic pain patients may also need to be assisted in accessing practices targeting specific conditions rather than general pain management yoga classes. Trials incorporating specific pain management practices have already been tested, with some promising findings. These include the ones for chronic neck pain [24] and chronic low back pain [25], for instance. Finally, there is an increased need to educate the general public about the benefits of these practices in order to achieve a beneficial health outcome rather than resorting solely to traditional therapies as the only way to achieve pain alleviation. As opposed to traditional therapies, when practiced correctly, yoga does not put the body under stress and may be less risky than other popular exercise regimes. The benefits of this complementary therapy are best ensured when carried out under supervised practice. This is particularly true for chronic pain patients.

\section{References}

1. International Association for the Study of Pain (2003) Pain: Clinical Updates.

2. Reid K J, Harker J, Bala MM, Truyers C, Kellen E, et al. (2011) Epidemiology of chronic non-cancer pain in Europe: Narrative review of prevalence, pain treatments and pain impact. Curr Med Res Opin 27(2): 449-462.

3. Dezutter J, Luyckx K, Wachholtz A (2015) Meaning in life in chronic pain patients over time: associations with pain experience and psychological well-being. J Behav Med 38(2): 384-396.

4. Vlaeyen JW, Crombez G, Goubert L, Liesbet Goubert (2007) The psychology of chronic pain and its management. Physical Therapy Reviews 12(3): 179-188.

5. Coughlin AM, Badura AS, Fleischer TD, Guck TP (2000) Multidisciplinary treatment of chronic pain patients: Its efficacy in changing patient locus of control. Arch Phys Med Rehab 81(6): 739-740.

6. Jackson T, Wang Y, Wang Y, Fan H (2014) Self-efficacy and chronic pain outcomes: A meta-analytic review. J Pain 15(8): 800-814.
7. Knaster P, Karlsson H, Estlander AM, Kalso E (2012) Psychiatric disorders as assessed with SCID in chronic pain patients: The anxiety disorders precede the onset of pain Gen HospPsychiat 34(1): 46-52.

8. Gupta RK, Brueh S, Burns JW, Buvanendran A, Chont M, et al. (2014) Relationship between endogenous opioid function and opioid analgesic side effects. Region Anesth Pain M 39(3): 219-224.

9. Gilron I, Jensen TS, Dickenson AH (2013) Combination pharmacotherapy for management of chronic pain: from bench to bedside. Lancet Neurol 12(11): 1084-1095.

10. Kristjánsdóttir ÓB, Fors EA, Eide E, Finset A, Lauritzen Stensrud T, et al. (2013) A smartphone-based intervention with diaries and therapistfeedback to reduce catastrophizing and increase functioning in women with chronic widespread pain: Randomized controlled trial. J Med Internet Res 15(1): e5.

11. Institute of Medicine of the National Academies (2011) Relieving pain in America: A blueprint for transforming prevention, care, education and research. Washington DC: The National Academies Press, USA.

12.Waddell G (2004) The Biopsychosocial Model. The Back Pain Revolution. Edinburch: Churchill Livingston.

13. Vlaeyen J, Linton S (2000) Fear avoidance and its consequences in musko-skeletal pain: A state of the art. Pain 85(3): 317-332.

14. Koes B (2010) Moderate quality evidence that compared to advice to rest in bed, advice to remain active provides small improvements in pain and functional status in people with acute low back pain. Roy Soc Med Int Cong 15(6): 171-172.

15. Feuerstein G (2011) The Encyclopedia of Yoga and Tantra. Boston: Shambhala Publications, USA.

16. Gaiswinkler L, Unterrainer HF, Fink A, Kapfhammer HP(2015) The relation between yoga immersion, psychological well-being and psychiatric symptoms. Neuropsychiatrie 29(1): 29-35.

17. Rissell AA, Miller BK, Lloyd LK, Williams JS (2014) Hot, sweaty and satisfied: Effects of Birkam yoga on psychological well-being. J Behav Health 3(1): 71-76.

18. Gard T, Noggle JJ, Park CL, Vago DR, Wilson A (2014) Potential in selfregulatory mechanisms of yoga for psychological health. Front Hum Neurosci 8: 770.

19. Baumeister RF, Vohs KD, Tice DM (2007) The strength model of selfcontrol. Current Directions in Psychological Science 16: 351.

20. Bussing A, Ostermann T, Ludtke R, Michalsen A (2012) Effects of yoga interventions on pain and pain associated disability: A meta-analysis. JPain 13(1): 1-9.

21. Dale LP, Carroll LE, Galen GC, Schein R, Bliss A, et al. (2011) Yoga practice may buffer the deleterious effects of abuse on women's self-concepts and dysfunctional coping. Journal of Aggression, Maltreatment \& Trauma 20(1): 90-102.

22. Tul Y, Unruh A, Dick BD (2011) Yoga for chronic pain management: A qualitative exploration. Scand J Caring Sci 25(3): 435-443.

23. Michalsen A, Traitteur H, Ludtke R, Brunnhuber, S, Meier, et al. (2012) Yoga for chronic neck pain: A pilot randomized controlled clinical trial. J Pain 13(11): 1122-1130.

24. Sang Dol K (2016) Effects of yoga on chronic neck pain: A systematic review of randomized controlled trials. J Phys Ther Sci 28(7): 21712174.

25. Holtzman S, Beggs RT (2013) Yoga for chronic low back pain: A metaanalysis of randomized controlled trials. Pain Res Manag 18(5): 267272 . 


Your next submission with Juniper Publishers
will reach you the below assets
- Quality Editorial service
- Swift Peer Review
- Reprints availability
- E-prints Service
- Manuscript Podcast for convenient understanding
- Global attainment for your research
- Manuscript accessibility in different formats
( Pdf, E-pub, Full Text, Audio)
- Unceasing customer service
Track the below URL for one-step submission
https://juniperpublishers.com/online-submission.php

